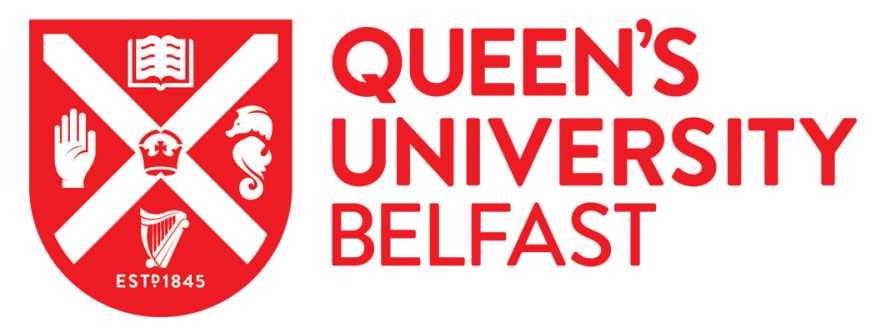

\title{
What is the relation between financial flexibility and dividend smoothing?
}

Fliers, P. T. (2019). What is the relation between financial flexibility and dividend smoothing? Journal of International Money and Finance, 92, 98-111. https://doi.org/10.1016/j.jimonfin.2018.12.009

Published in:

Journal of International Money and Finance

Document Version:

Peer reviewed version

Queen's University Belfast - Research Portal:

Link to publication record in Queen's University Belfast Research Portal

\section{Publisher rights}

Copyright 2019 Elsevier.

This manuscript is distributed under a Creative Commons Attribution-NonCommercial-NoDerivs License

(https://creativecommons.org/licenses/by-nc-nd/4.0/), which permits distribution and reproduction for non-commercial purposes, provided the author and source are cited.

\section{General rights}

Copyright for the publications made accessible via the Queen's University Belfast Research Portal is retained by the author(s) and / or other copyright owners and it is a condition of accessing these publications that users recognise and abide by the legal requirements associated with these rights.

Take down policy

The Research Portal is Queen's institutional repository that provides access to Queen's research output. Every effort has been made to ensure that content in the Research Portal does not infringe any person's rights, or applicable UK laws. If you discover content in the Research Portal that you believe breaches copyright or violates any law, please contact openaccess@qub.ac.uk. 


\title{
What is the relation between financial flexibility and dividend smoothing?*
}

Philip T. Fliers

October 2018

\begin{abstract}
This paper investigates the relation between financial flexibility and dividend smoothing policies. We use two proxies for financial flexibility; we measure levels of unused debt capacity and capital structure adjustment speeds. We find a nonlinear relation between unused debt capacity and dividend smoothing. For firms with high levels of unused debt capacity, this relation is positive. However, we find a negative effect for firms with low levels of unused debt capacity. Additionally, we show a positive relation between capital structure adjustment speeds and dividend smoothing. We find that firms absorb shocks to net income by changing their capital structure, and this change enables dividend smoothing. The effects we document are stronger for positive changes to a firm's net income. (119 words)
\end{abstract}

Keywords: dividend smoothing, capital structure, financial flexibility, debt capacity, Lintner, partial adjustment

JEL classification: D22, G34, G35.

\footnotetext{
${ }^{*}$ We are grateful for the suggestions and comments made by an anonymous referee. This paper has greatly benefited from comments from Bill Francis, Amit Seru, John Kose, Meziane Lasfer, Abe de Jong, Peter Roosenboom, Chris Colvin, Gerarda Westerhuis, Florian Madertoner, Pooyan Ghazizadeh, Elisabeth Maes, Henry van Beusichem, Barry Quinn, Chris Veld, John Turner, Wolf Wagner, Dirk Schoenmaker, Marc Deloof, Dimitris Andriosopoulos, Samuele Murtinu, James Thewissen, participants in the 13th Corporate Finance Day in Ghent, participants in the 6th International Conference of the Financial Engineering and Banking Society in Malaga, participants in the 14th Corporate Finance Day in Antwerp and participants in the Paris Financial Management Conference 2016. This paper benefited greatly from support and data access at the Rotterdam School of Management, Erasmus University, where most of it was developed.
} 


\section{Introduction}

Since Lintner (1956) first made his observation of dividend smoothing, this phenomenon has become well-documented. However, the literature has failed to reach a consensus on why firms smooth their dividends. ${ }^{1}$ Furthermore, only a limited number of studies examine the crosssectional determinants of dividend smoothing. ${ }^{2}$ This study provides a new and, until now, undocumented determinant of dividend smoothing.

Using Lintner's (1956) model, we examine how financial flexibility relates to dividend smoothing. We define financial flexibility as the firm's ability to adjust its capital structure (Gamba and Triantis, 2008 and De Jong et al., 2012). To measure the firm's financial flexibility, we use two distinct proxies. First, we calculate the firm's unused debt capacity. The firm's unused debt capacity is the amount of debt the firm can issue before losing its investment grade status (De Jong et al., 2012). This measure captures the firm's borrowing potential. Second, we measure capital structure adjustments speeds (e.g., Fama and French, 2002; Flannery and Rangan, 2006). This factor represents the firm's historical ability to realize capital structure changes. We interpret this proxy as a broad measure of costs associated with capital structure adjustments (Flannery and Rangan, 2006). That is, firms with higher capital structure adjustment speeds face lower costs when increasing or decreasing their leverage. ${ }^{3}$

There are three explanations for dividend smoothing. First, the information asymmetry between shareholders and managers prompts dividend smoothing behavior (e.g., Kumar, 1988; Guttman et al., 2010). Second, dividend smoothing arises as a way to limit the agency costs of free cash flow (e.g., DeAngelo and DeAngelo, 2007; Lambrecht and Myers, 2012). Third, the existence of external finance costs prompts firms to stabilize their dividends (e.g., Miller and Scholes, 1978; Aivazian et al., 2006). In addition to existing determinants of dividend smoothing, we argue that financial flexibility is also important. ${ }^{4}$

Using a dynamic agency model, Lambrecht and Myers (2012) show that changes in dividends follow Lintner's (1956) partial adjustment model. In their model, risk averse managers make decisions about the firm's dividend policy and prefer dividend smoothing. The purpose of

\footnotetext{
${ }^{1}$ For example, Berk and Demarzo (2007), Leary and Michaely (2011) and Farre-Mensa et al. (2014).

${ }^{2}$ For example, Dewenter and Warther (1998), Aivazian et al. (2006), Michaely and Roberts (2011) and Leary and Michaely (2011).

${ }^{3}$ For example, costs associated with leverage increases are higher bankruptcy costs, hence higher cost of capital. Costs associated with leverage decreases (by retaining profits or paying down debt) are, for example, increased agency costs as in Jensen (1986).

${ }^{4}$ Leary and Michaely (2011) provide an extensive summary of the theoretical work that explains the prevalence of dividend smoothing and its most important determinants.
} 
which is easing out shocks to the firm's income. Lambrecht and Myers (2012) also predict that if dividends are smooth; then, something else has to absorb fluctuations in income. Assuming investments are sticky, they argue that the firm's capital structure must absorb shocks to the firm's income. That is, the firm's ability to change its capital structure enables dividend smoothing. As such, our main hypothesis follows Lambrecht and Myers (2012) and states that financially flexible firms have more stable dividends.

We explain cross-sectional differences in dividend smoothing. We use data for all firms in both the CRSP and Compustat databases over the period from 1986 to 2013. Similar to other studies examining dividend smoothing, we focus our attention on dividend-paying firms. For estimating dividend smoothing and capital structure adjustment speeds, we require each firm to have at least 10 years of consecutive observations in the data. After applying all criteria, we have 517 firms and in total 5,159 firm-year observations. ${ }^{5}$ Our sample contains the most likely candidates to exhibit dividend smoothing. This identification is consistent with prior literature (e.g., Fama and Babiak, 1968; DeAngelo et al., 2004; Leary and Michaely, 2011).

Our main findings are as follows. There is a nonlinear relation between unused debt capacity and dividend smoothing. For firms with high levels of unused debt capacity, this relation is positive. Indeed, firms tap into their debt capacity to smooth dividends, consistent with the predictions from Lambrecht and Myers (2012). However, for firms with low levels of unused debt capacity, a negative relation is found. These firms avoid additional smoothing of dividends. We conclude that these firms change their payouts quickly in response to changes in income. This behavior reduces information asymmetry, the benefit of which is that firms preserve (low-cost) access to public debt markets. This finding is consistent with prior literature (e.g., Denis, 2011; Leary and Michaely, 2011). ${ }^{6}$

We find a positive relation between capital structure adjustment speeds and dividend smoothing. Firms that adjust their capital structure quickly smooth their dividends more. We interpret capital structure adjustment speeds as a broad measure of the costs a firm faces when

\footnotetext{
${ }^{5}$ These firms constitute approximately $35 \%$ of all on-balance sheet assets and approximately $45 \%$ percent of all dividends paid. Our sample contains large and mature firms. Additional information on the justification of our sample is available from the authors upon request. Additionally, we find that the firms in our sample pay very stable dividends, on average 31 percent more stable compared to the average firm in the Compustat universe, as measured by the relative volatility metric used by Leary and Michaely (2011).

${ }^{6}$ Lambrecht and Myers (2012) also highlight that managers who are risk averse do not maximize market value. They forgo positive NPV projects, which implies they underinvest. By adjusting dividends quickly firms mitigate the costs of underinvestment. This finding is consistent with the literature on of financial constraints and access to public debt markets with respect to dividend smoothing (e.g., Leary and Michaely, 2011; Aivazian et al., 2006).
} 
changing its capital structure. As such, when firms face low capital structure adjustment costs, they will smooth their dividends more.

We then test the prediction of Lambrecht and Myers (2012) that the firm's capital structure absorbs shocks to net income in order to enable dividend smoothing. We identify two types of shocks: positive and negative changes in net income. Additionally, we identify severe shocks (fourth quartile changes in net income). We consider shocks to be absorbed when changes in net income do not lead to changes in dividends. We find that firms will always attempt to absorb shocks to net income. However, the way different shocks are absorbed is asymmetric, as positive shocks and negative shocks are not absorbed equally.

We find that severe positive shocks are absorbed better when capital structure adjustment speeds are high. That is, firms that are able to adjust their capital structure quickly in response to a severe positive shock smooth their dividends more. We conclude that severe positive shocks expose firms to the agency costs of excess cash and hence prompt smoothing behavior (Leary and Michaely, 2011; DeAngelo and DeAngelo, 2007). However, for severe negative shocks, we find the following. First, severe negative shocks decrease dividend smoothing. Second, in the case of a severe negative shock, firms do not tap into their debt capacity. Our findings are consistent with recent literature. For example, Leary and Michaely (2011) find that dividend smoothing is most prevalent among firms that face no constraints and are most susceptible to agency conflicts. Also, Hoang and Hoxha (2016) show that the firm's capital structure absorbs approximately 57 percent of the variation in net income. Daniel et al. (2010) show that firms use capital structure policies to absorb financial shocks while only making adjustments to dividend payments.

From our analysis, we draw three main conclusions. First, the firm's capital structure is the shock absorber that enables dividend smoothing, as predicted by Lambrecht and Myers (2012). Second, dividend smoothing is stronger at high levels of unused debt capacity and higher capital structure adjustment speeds. Third, the nature of the shocks determines the degree of smoothing, an attribute not predicted by Lambrecht and Myers (2012). Moreover, previous empirical work has treated the absorption of shocks by the firm's capital structure as homogeneous for both negative and positive changes in the firm's income (Daniel et al. 2010; Hoang and Hoxha, 2016).

We make two distinct contributions to the literature. First, we explicitly test the predictions of Lambrecht and Myers (2012). The estimation of Lintner's partial adjustment model allows us to test the predictions from a dynamic agency model. Second, we show that financial flexibility, 
as measured by unused debt capacity and capital structure adjustment speed, is an important determinant of dividend smoothing. We document that for large and mature firms, financial flexibility is an important consideration in setting dividend policies.

The remainder of this paper is structured as follows. Section 2 elaborates on the explicit hypotheses tested. Section 3 describes the data selection and methods. Section 4 explains the results. Section 5 provides a discussion and concludes.

\section{Hypotheses}

Lintner (1956) provides no theoretical underpinning for the observed dividend smoothing. Lambrecht and Myers (2012) use a dynamic agency model and formally derive Lintner's partial adjustment model. In their model, risk averse managers make decisions on the firm's dividend policy. ${ }^{7}$ Lambrecht and Myers (2012) show that when managers are risk averse, dividends are smooth. The purpose of this smoothing is easing out shocks to the firm's income. Lambrecht and Myers (2012) predict that if dividends are smooth, then another cashflow has to absorb fluctuations in income. Assuming investments are sticky, they argue that the firm's capital structure must absorb shocks to the firm's income. Three assumptions are therefore important. First, dividend cuts are costly (e.g., Myers, 1984). Second, firms have an incentive to preserve low-cost access to debt markets (DeAngelo and DeAngelo, 2007; Denis, 2011; Leary and Michaely, 2011). Third, unconstrained firms with access to public debt markets smooth their dividends more (Leary and Michaely, 2011; Aivazian et al., 2006). Firms with sufficient financial flexibility will prefer to avoid cutting dividends and prefer access to capital markets to utilize their unused debt capacity. ${ }^{8}$ We conclude that firms do this by smoothing their dividends.

H1: There is a positive relation between financial flexibility and dividend smoothing

\footnotetext{
${ }^{7}$ While Lambrecht and Myers (2012) consider total payouts (i.e. cash and stock dividends), the focus of this paper is on Lintner-like dividend smoothing behavior. Our analysis is primarily concerned with the payment of cash dividends. In our robustness analysis, we consider repurchases. Our results remain unchanged.

${ }^{8}$ In addition, in the short term, Lambrecht and Myers (2012) assume that the firm faces a finite set of investment opportunities. In their model, the risk-averse do not maximize market value. They forgo positive NPV projects when facing constraints, which implies they underinvest. The cost of underinvestment (i.e., reduced capital market access), can be mitigated by the firm's payout policy. However, when managers face no constraints, the resulting dividend smoothing is also used to preserve low-cost access to capital markets.
} 
We conclude that if the firm's capital structure absorbs shocks to the firm's income to enable dividend smoothing, it is beneficial to do so when there is sufficient unused debt capacity. This idea is consistent with prior literature. For example, Fama and French (2002) find that firms with many investment opportunities pay fewer dividends in order to maintain a low-risk debt capacity. De Jong et al. (2012) show that firms with more unused debt capacity invest more in future years. These observations suggest that firms set their debt and dividend policies to take advantage of retained earnings. Moreover, Aivazian et al. (2006) show that firms with publicly traded debt (i.e., firms that have a credit rating) smooth their dividends more. Leary and Michaely (2011) find that dividend smoothing is most prevalent among firms that face no constraints and are most susceptible to agency conflicts.

However, Lemmon and Zender (2010) show that it is relatively small, high-growth firms that face the most restrictive debt capacity. ${ }^{9}$ This implies that firms facing restricted debt capacity have an incentive to preserve access to public debt markets. That is, firms with restricted debt capacity change their payouts quickly in response to changes in income. This behavior reduces information asymmetry, the benefit of which is that firms preserve (low-cost) access to public debt markets. This conjecture is consistent with previous literature (e.g., DeAngelo and DeAngelo, 2007; Denis, 2011; Leary and Michaely, 2011). In the spirit of Lambrecht and Myers (2012), we state that dividend smoothing behavior is especially strong at high levels of unused debt capacity.

$\mathrm{H}$ 2: At higher levels of unused debt capacity, the positive relation between financial flexibility and dividend smoothing is stronger

One of the more recent explanations for dividend smoothing choices has been the existence of external financing costs (Miller and Scholes, 1978; Almeida et al., 2004; Aivazian et al., 2006). For example, firms have an incentive to limit external financing costs and to maintain low-cost access to capital markets (Faulkender et al., 2012). Studies such as Leary and Roberts (2005), Hovakimian (2006), and Alti (2006) show that firms rebalance their leverage ratios when they could either borrow more or face high costs of external financing. Survey evidence by Graham and Harvey (2001) shows that $81 \%$ of firms do indeed have an implicit or explicit debt ratio target. However, adjustment costs may prevent an immediate adjustment to a firm's target, since the firm

\footnotetext{
${ }^{9}$ While we only focus large and mature firms, there is cross-sectional variation in levels of unused debt capacity.
} 
trades its adjustment costs against the costs of operating with suboptimal leverage (Flannery and Rangan, 2006; Faulkender et al., 2012).

Thus, the firm's ability to change its capital structure depends on the adjustment costs that the firm faces. That is, the extent to which firms use as a transitory mechanism to cover the shortfall in operations depends on the costs that a firm faces (Denis and McKeon, 2012). ${ }^{10}$ Moreover, Faulkender et al. (2012) find that firms that pay dividends adjust their capital structure more quickly than firms that do not. This can be explained by the firm's objective of maintaining its low-risk debt capacity and its incentive to preserve low-cost access to capital markets. If adjustments to the firm's capital structure enable dividend smoothing, it is beneficial for firms to do so when the costs of those adjustments are low. We conclude that firms that face low capital structure adjustment costs will smooth their dividends more.

$\mathrm{H} 3$ : There is a negative relation between capital structure adjustment costs and dividend smoothing

\section{Data and methods}

\subsection{Sample selection}

We use the data for all firms in both the CRSP and Compustat databases over the period from 1986 to 2013. We exclude financial firms (SIC codes 6000-6999) and utilities (4000-4999). Contrary to Leary and Michaely (2011), we limit the sample to those firms that have paid a dividend in at least 10 of the years in our sample. ${ }^{112}$ We require firms to have information on the control variables used. After applying all the criteria, we have 517 firms, from which we derive 5,159 firm-year observations (an average of approximately 10 years of data per firm). This identification

\footnotetext{
${ }^{10}$ Although Lambrecht and Myers (2012) do not assume that a firm's decisions about its capital structure follow a partial adjustment model, we use the adjustment speeds from the partial adjustment models as a proxy for the firm's ex ante observed costs of changing its capital structure. Fischer et al. (1989) argue that a firm will adjust its leverage only if the benefits of doing so more than offset the costs of reducing the firm's deviation from its leverage target. Altinkilic and Hansen (2000) present estimates of the costs of issuing securities, and others have modeled the impact of transaction costs on observed leverage patterns (e.g., Strebulaev, 2007; Stefanescu and Shivdasani, 2010; Korajczyk and Levy, 2003; Leary and Roberts, 2005).

${ }^{11}$ This criteria is a large strain on the maximum number of observations used in our analysis. However, we are interested in selecting the most likely candidates to exhibit dividend smoothing behavior. That is, we have selected those firms with a credible dividend payment history. More specifically, our analysis shows that our sample firms constitute approximately $35 \%$ of all on-balance sheet assets and approximately $45 \%$ percent of all dividends paid. Our sample contains large and mature firms. Additional information on the justification of our sample is available from the authors upon request. Additionally, we find that the firms in our sample pay very stable dividends, on average 31 percent more stable compared to the average firm in the Compustat universe.

${ }^{12}$ When we allow firms into our sample when they have omitted their dividends 1, 2, or three times, our sample does not increase significantly, as we require a minimum of 10 observations. By focusing on firms that always pay a dividend we deviate from the setup from Leary and Michaely (2011). However, when we include firms that omit dividends (i.e., those firms that prefer "flexibility" in their payout), no more than 50 percent of the time, our results remain robust.
} 
is consistent with prior literature. ${ }^{13}$ Moreover, our selection criteria provides several distinct advantages.

First, the identification severely limits the between firm variation in both dividend smoothing policies and capital structure choice, increasing the difficulty of finding undocumented determinants of dividend smoothing. Second, it allows us to estimate firm-specific time-varying Lintner-like partial adjustment models to capture the firm's dividend smoothing behavior. Third, it allows us to estimate firm-specific time-varying partial adjustment models for the firm's capital structure. ${ }^{14}$ Fourth, it allows us to circumvent endogeneity concerns with respect to the firm's choice to pay dividends. We conclude that our sample contains the most likely candidates for dividend smoothing. In the spirit of Lambrecht and Myers (2012) we have selected those large and mature firms with a credible dividend payment history.

\subsection{Measuring dividend smoothing}

The partial adjustment hypothesis, as introduced by Lintner (1956), holds that managers recognize the transitory nature of their earnings. Lintner concludes that managers need a dividend discipline. That is, previous dividend levels and current earnings determine current changes in dividends. The firm's desired level of dividends $\left(\operatorname{Div}^{*}\right)$ is given by:

$$
\operatorname{Div} v_{t}^{*}=r E_{t}
$$

where $E_{t}$ is the firm's current earnings and $r$ is the firm's target payout ratio. Lintner (1956) concludes that when earnings increase and there is uncertainty about the sustainability of those earnings, dividends will not fully adjust. Given the costly nature of dividend cuts, changes in dividends will be only gradual. As such, we estimate the following partial adjustment model:

$$
\Delta \operatorname{Div}_{t}=\alpha+\beta_{1} E_{t}+\beta_{2} \text { Div }_{t-1}+\epsilon_{t} ; \forall \text { firms at time } t
$$

where $\Delta D i v_{t}$ is the change in dividends, $D i v_{t-1}$ are the dividends paid in the previous periods. The firms target payout ratio is then given by $\beta_{1} / \beta_{2}$, and the dividend speed of adjustment (SOA)

\footnotetext{
${ }^{13}$ See for example Fama and Babiak (1968), Aivazian et al. (2006) and Leary and Michaely (2011).

${ }^{14}$ Similar to the models estimated by Fama and French (2002) and Flannery and Rangan (2006).
} 
is then given by $-\beta_{2} \cdot{ }^{15}$ The interpretation is as follows: firms with a higher SOA adjust their dividends more quickly. A higher SOA means more volatility in the firm's dividend payments. Firms that smooth their dividends have a low SOA.

\subsection{Measuring financial flexibility}

Unused debt capacity. De Jong et al. (2012), calculate a firm's debt capacity by predicting the debt level at which a firm has a p\% chance of losing its investment-grade rating, given the firm's other characteristics. We choose this cut-off point as the point beyond which (a) distress probabilities increase significantly, (b) external financing costs increase rapidly and (c) default probabilities increase. We use the firm's credit rating to estimate an ordered response model:

$$
\mathrm{y}_{i, t}^{*}=\alpha_{1} d r_{i, t}+x_{i t}^{\prime} \alpha_{2}+\epsilon_{i, t}
$$

where $y_{i, t}^{*}$ is the firm's credit rating, $x_{i, t}^{\prime}$ is a set of firm characteristics and $d r_{i, t}$ is the firm's debt ratio. ${ }^{16}$ The ordered response model provides the boundaries $(\gamma)$ between different credit ratings. An investment grade rating corresponds to a point where $\gamma_{i, t} \geq 4$ and $\gamma_{i, t}^{*} \geq \gamma_{3}$. We then estimate the firm's debt capacity $d c_{i, t}$ by determining the expected value of $\gamma_{i, t}^{*}$. This expected value is conditional on the firm's current rating and by comparing this value with the threshold $\gamma_{3}$, we derive $d c_{i, t}$ by solving:

$$
\alpha_{1} d c_{i, t}+x_{i, t}^{\prime} \alpha_{2}+E\left\{\epsilon_{i, t} \mid y_{i, t}, x_{i, t}, d r_{i, t}\right\}
$$

The probability of having a speculative-grade rating, conditional on the current rating and firm characteristics is then given by

$$
P\left\{y_{i, t}^{*}<\gamma_{3}\right\}=P\left\{\alpha_{1} d r_{i, t}+x_{i, t}^{\prime} \alpha_{2}+\lambda_{i, t}+\epsilon_{i, t}<\gamma_{3}\right\}
$$

\footnotetext{
${ }^{15} \mathrm{SOA}$ is thus an inverse metric. We measure this metric for each firm at each point in each time. As such, we require each firm to have at least 10 consecutive observations to allow for a robust rolling window estimation of the dividend adjustment speed at time t. The mid-points of these estimations are then matched with the control variables and variables of interest at that point in time, over the period from 1986 to 2008.

${ }^{16}$ For the firm's credit rating we use a 7-point rating scale (ranging from AAA to CCC \& D) following Ashbaugh-Skaife et al. (2006). The set of firm characteristics are included and orthogonalized with respect to the firm's debt ratio. We do this to examine the effect of leverage on credit ratings.
} 
where $\lambda_{i, t}$ is the generalized residual for individual firms and is positive for firms with unexpectedly high credit ratings. We assume that $\epsilon_{i, t}$ follows an F-distribution with $F^{-1}($.$) as its$ inverse. We define the debt capacity as the value for $d r_{i, t}$ that results in a probability of $\mathrm{p} \%$ of receiving a speculative rating. It is then the solution to

$$
P\left\{\alpha_{1} d r_{i, t}+x_{i, t}^{\prime} \alpha_{2}+\lambda_{i, t}+\epsilon_{i, t}<\gamma_{3}\right\}=p
$$

which yields

$$
d c_{p, i, t}=\frac{\gamma_{3}-x_{i, t}^{\prime} \alpha_{2}+\lambda_{i, t}-F^{-1}(p)}{\alpha_{1}}
$$

Then, to measure the firm's financial flexibility, we use the difference between the debt capacity as defined in (7) and the debt ratio at time t. ${ }^{17} 18$

Capital structure adjustment costs. As a second proxy for a firm's financial flexibility, we use the speed of adjustment of its capital structure. A high adjustment speed represents low adjustment costs. To determine the firm's leverage target, we employ a standard partial adjustment model. We estimate year-by-year cross-section regressions with Fama-McBeth time-series standard errors:

$$
d r_{i, t+1}=\alpha_{1}+\alpha_{2} x^{\prime}+\epsilon_{i, t}
$$

where $d r$ is the firm's leverage ratio and $x^{\prime}$ is a set of standard variables as in Fama and French (2002). We then use the fitted value from (8) as a proxy for the firms target debt ratio $\left(d r_{i, t}^{*}\right)$. Then, to calculate the firm's capital structure adjustment speeds, we estimate:

$$
d r_{t+1}-d r_{t}=\alpha_{1}+\alpha_{2}\left[d r_{t}^{*}-d r_{t}\right]+\epsilon_{t} ; \forall \text { firms at time } t
$$

\footnotetext{
${ }^{17}$ We assume that at $p=0.2$, much like De Jong et al. (2012), the firm has reached the end of its debt capacity when rating agencies are considering a down rate. The alternative would be to assume a probability above $50 \%$. However, by construction, the choice of a value for $\mathrm{p}$ however has no impact on the results presented in our multivariate analysis.

${ }^{18}$ For additional information on the estimation, see De Jong et al. (2012). The results of the ordered logit estimation are available from the authors upon request.
} 
where $\alpha_{2}$ is the speed of adjustment for the firm's capital structure. ${ }^{19}$

\subsection{Explaining cross-sectional variation in dividend smoothing}

To test our hypotheses, we explain cross-sectional variations in dividend smoothing for large and mature firms with a history of dividend payments. Our variables of interest are the firm's unused debt capacity and the firm's capital structure adjustment speed. Additionally, we calculate the extent to which a firm experiences a shock to net income (scaled by total assets). We define a shock as a change in the firm's net income that is economically relevant to the firm (i.e., larger than $2 \%) .{ }^{20}$ To explain corporate smoothing behavior, we then estimate the following base equation:

$$
S O A_{i, t}=\alpha+\beta_{1} C_{i, t}+\beta_{2} I_{i, t}+\kappa+\omega+\psi+\epsilon_{i, t}
$$

where $S O A_{i, t}$ is the firm's dividend adjustment speed (inverse metric). $C_{i, t}$ is a vector of firmspecific control variables, which include leverage, $\mathrm{m} / \mathrm{b}$, firm size, cash holdings, profitability, tangibility and earnings volatility. In robustness analysis we also include alternative measures for financial constraints, target payouts, share repurchases, information asymmetry, governance and taxes. $I_{i, t}$ are the variables of interest, including unused debt capacity and the speed of capital structure adjustment. We specify our models as Feasible Least Squares estimations, with an identity link function $(X \beta=\mu)$. We correct for a heteroskedastic error structure with no crosssectional correlation. All estimations include industry fixed effects $(\kappa)$, year fixed effects $(\omega)$, and age decile fixed effects $(\psi) .^{21}$

\footnotetext{
${ }^{19}$ Because we use rolling window regressions to estimate the adjustment speeds, there are implications for our estimates: (1) the firm's actual debt ratio eventually converges with its target debt ratio, (2) there is cross-sectional variation in $\alpha_{2}$ and (3) $\alpha_{2}$ varies over time. Flannery and Rangan (2006) and others find evidence that firm characteristics affect capital structure adjustment speeds. Our subsequent analysis considers this. Additionally, we correct our estimates for its persistence. Our estimates for the firm's capital structure adjustment speeds are higher but comparable to those in earlier literature. The fact that our estimate for $\alpha_{2}$ is higher comes from the fact that we deal solely with dividend-paying firms. Moreover, Faulkender et al. (2012) find that firms that pay dividends adjust their capital structure more quickly than firms that do not.

${ }^{20} \mathrm{We}$ consider this value economically relevant, since firms payout approximately $2 \%$ of their assets. Alternative definitions yield very similar results.

${ }^{21}$ We use the age deciles to account for any potential life-cycle effect that might be reflected in the firm's dividend smoothing policies or our variables of interest. Fama and French (2001), Grullon et al. (2002), and DeAngelo et al. (2006) all use some form of life-cycle arguments for dividend policy. More specifically, as put by DeAngelo et al. (2006, p. 228): "Dividends tend to be paid by mature, established firms, plausibly reflecting a financial life cycle in which young firms face relatively abundant investment opportunities with limited resources so that retention dominates distribution, whereas mature firms are better candidates to pay dividends because they have higher profitability and fewer attractive investment opportunities." When excluding the age-decile effects from our analysis, our results remain robust.
} 
Our dependent variable is estimated using rolling window regressions and panel-specific AR1 autocorrelation structure (e.g., Byoun, 2008). The autocorrelation parameter is specified by the Durbin-Watson statistic $\left(d=\frac{\sum_{t=2}^{T}\left(\epsilon_{t}-\epsilon_{t-1}\right)^{2}}{\sum_{t=2}^{T} \epsilon_{t}^{2}}\right) .{ }^{22}$ Since $S O A_{i, t}$ is an estimate, we weigh the dependent variable by the inverse of its estimation error. This allows us to put more weight on more accurately measured observations.

\subsection{Ex ante capital structure choice}

Consistent with Lambrecht and Myers (2012) and Lambrecht and Myers (2017), the firm's leverage is persistent over time. That is, firms may have a debt policy in place that is not fully related to dividend policy. We distinguish two types. First, firms might choose to use very high debt levels, for example, as a way to discipline managers. We find that firms that choose to maintain high leverage impede their unused debt capacity, have relatively limited unused debt capacity, are approximately $2.2 \%$ less profitable and have lower earnings volatility. We estimate the conditional probability that a firm ex ante chooses to have high leverage (above industry year-median) and include this in our models as the inverse Mills ratio of the appropriate binary response model. ${ }^{23}$

Second, firms may have an incentive to preserve low levels of unused debt capacity, which is in a way unrelated to any dividend policy. This is consistent with De Jong et al. (2012). They show that firms with high levels of unused debt capacity invest more in future years and should thus smooth their dividends accordingly to maintain a low-risk debt capacity. We find that firms that choose to maintain high levels of unused debt capacity have more growth opportunities, adjust their capital structure approximately $2.6 \%$ more quickly, are more profitable and are the largest firms in our sample. We correct our estimations for the conditional probability that firms ex ante choose to maintain high levels of unused debt capacity and include this in our model as the inverse Mills ratio of the appropriate binary response model. ${ }^{24}$

We use US government shutdowns as an additional variable. The aim of this variable is to capture an exogenous shock that reduces market valuations, decreases borrowing capacities and

\footnotetext{
${ }^{22}$ This particular correction requires each firm in our sample to have at least two consecutive observations in our final sample even after all variables of interest, control variables and robustness variables have been calculated.

${ }^{23}$ The appropriate descriptive statistics are available upon request.

24 The appropriate descriptive statistics are available upon request.
} 
increase economy-wide uncertainty. If the firm's capital structure is a shock absorber, government shutdowns will leave the firm's dividend policy unaffected. We define a government shutdown as the point in time when the US Congress chooses not to pass legislation funding government operations and agencies. Kosar (2004) notes that before the fiscal year for the US government ends on September 30th, the president has to sign 13 appropriation bills, and failing to do so will halt all nonessential government spending, triggering a shutdown. A failure to sign the appropriate bills will create a funding gap. At which point programs and businesses that receive funding are curtailed and possibly halted altogether. We argue that this shock is absorbed by the firm's capital structure and affects the probability of maintaining high leverage and lower levels of unused debt capacity. More intuitively, we argue that large and mature firms, which are more likely to have government contracts, are able to mitigate the shocks induced by the curtailment of government funding. ${ }^{25}$ They use their financial flexibility to absorb this shock.

That these shutdowns are economically relevant becomes apparent from the estimated costs. For example, Meyers (1997) highlights the fact that small businesses and local governments faced losses of approximately 295 million dollars during the 1996 shutdown. Kosar (2004) points out that during the 1996 shutdown, more than $20 \%$ of all Washington-area contractors were affected (totaling approximately 3.7 billion dollars in contract value). In 2015, S\&P estimated that a government shutdown costs approximately 1.5 billion dollars per day ( $0.6 \%$ of GDP growth). Here, we argue that these government shutdowns are a good measurement, because this type of shock does impair the financial flexibility of a firm through reduced market valuations, although it does not affect the firm's dividend policy.

During our sample period, we observe five of these shocks. Two government shutdowns occurred during the years that Ronald W. Reagan was president (1986 and 1987). One government shutdown occurred while George H.W. Bush was in office (1990) and two shutdowns occurred while Bill J. Clinton was president (1995 and 1996). We find that in a period of five days following the announcement of a shutdown the average Compustat firm had a cumulative abnormal return of approximately -98 basis points. We argue that investors subsequently adjust their risk premium for future funding, increasing borrowing costs while firms leave their dividend policies unimpeded. Our specific sample firms substantially outperformed other firms by approximately 35 basis points on the day of and after the announcement and 144 basis points in the 5 days

\footnotetext{
${ }^{25}$ Forbes recently estimated that only $22.5 \%$ of all contracts are awarded to small firms.
} 
following a shutdown. ${ }^{26}$ This finding is consistent with the idea that firms that are financially more flexible are expected to cope better with the consequences of a government shutdown. This being the case, we define our additional variable as an indicator that equals 1 if at time $t$ or at $t-1$ the US government experienced a shutdown and include it in the following probit model:

$$
\operatorname{Pr}\left(Y_{i, t}=1 \mid X_{i, t}\right)=\alpha+\phi\left(X_{i, t}^{\prime} \beta_{1}\right)+\phi\left(Z_{t}^{\prime} \beta_{2}\right)+\omega+\epsilon_{i, t}
$$

The choice variable $\left(Y_{i, t}\right)$ is above the year-industry median leverage (unused debt) capacity, and standard controls are included. ${ }^{27}$ We subsequently derive the inverse Mills ratio, capturing the conditional probability of the aforementioned choices.

Because government shutdowns are rare and are all inadvertently treated equally, we test the robustness of our findings using a related variable. As an alternative, we use the number of days that the US government required continuing resolutions (CRs) to avoid a shutdown. Joyce (2012) highlights the economic impact of uncertainty about the appropriation of government funds. Although in recent years the US government has avoided costly shutdowns, the extent of late and temporary appropriations have increased. We measure how many days per annum were covered by a CR and define our variable as a dummy variable which equals one if and only if at time $t$ the number of days covered by a CR was above the 6-year mean. Our results are fully robust to this alternative. $^{28}$

\section{Results}

Table 2 provides descriptive statistics for all the variables of the firms in our sample. The median firm in our sample has a balance sheet size of almost 3 billion dollars, has a M/B larger than 1 and has been included in CRSP for 38 years. These firms pay very stable dividends. We compare the average relative volatility metric from Leary and Michaely (2012) between our

\footnotetext{
${ }^{26}$ An overview of all shutdowns in our sample and the associated cumulative abnormal returns around the shutdown dates are available upon request.

${ }^{27}$ All estimations are available upon request. We find that firms have a higher propensity to maintain high leverage levels when there market wide value losses due to a halt in government funding appropriations. That is, firms have an incentive the use debt to cover their ongoing operations in excess of normal adjustments to macro-economic fluctuations. Moreover, in times of uncertainty, firms choose to impede their debt capacity in case of a government shutdown. The argument that firms would draw on their line of credit in anticipation of a shutdown and would give the same result, might seem valid at first. However, our variable spans over multiple years. If this effect was driven by anticipation it would quickly resolve when the shutdown ends. Additionally, the inclusion of time fixed effects eliminates the possibility that these results are caused by credit line and business cycle effects.

${ }^{28}$ In the discussion of our results, we also report that both government shutdowns and continuing resolutions do not impact other variables in our analysis through which the shock can affect dividend policies.
} 
sample firms and the entire Compustat universe. We find the dividends of the firms in our sample are approximately 31 percent more stable in their dividend payments. This illustrates how closely these firms resemble the firms described in Lambrecht and Myers (2012). ${ }^{29}$

\subsection{Baseline model}

Table 3 shows the buildup of our baseline model. Column 1 only includes our control variable. We find that firms that have more leverage smooth dividends more. A one standard deviation increase in leverage will prompt firms to smooth their dividends approximately 4.3 percent more. ${ }^{30}$ This finding is consistent with the idea that debt ratios reflect the firm's cumulative requirements for external funds. This implies that firms that have constrained debt capacities will have a preference to maintain access to capital markets and will smooth their dividends. Moreover, we find that firms with more tangible assets and consequently lower levels of information asymmetry indeed smooth their dividends less. In addition, we find that more risky firms (earnings volatility) are more likely to smooth their dividends. ${ }^{31}$ Moreover, we show that, inconsistent with the findings of Leary and Michaely (2011), larger firms smooth their dividends less. ${ }^{32}$

Column 2 then includes the inverse Mills ratio for leverage. We find no statistically significant effect. Column 3 includes both a linear term and a squared term for unused debt capacity. Additionally, we correct our estimates with the inverse Mills ratio for unused debt capacity. We find that there is a negative bias, the inverse Mills ratio for unused debt capacity is statistically significant. ${ }^{33}$ More importantly, in line with our hypotheses, both the linear and squared term of unused debt capacity are statistically significant and with opposing signs. Column 4 includes the firm's capital structure adjustment speed. We find, in line with our hypothesis, firms that adjust their capital structure more quickly (i.e., those that face low adjustment costs) will smooth their dividends more. More explicitly, a one standard deviation increase in capital structure adjustment speed will lead to 2.5 percent more dividend smoothing.

\footnotetext{
${ }^{29}$ Compared to the Compustat universe, our sample firms are approximately 5 times larger and have been listed in the CRSP database approximately twenty-one years more.

${ }^{30} \mathrm{SOA}$ is an inverse metric; negative regression coefficients should be interpreted as more dividend smoothing.

${ }^{31}$ This finding is consistent with the predictions from Lambrecht and Myers (2012) and prior findings by Kumar and Lee (2001).

${ }^{32}$ We argue that in the presence of relatively small firms, we might obtain the same findings as Leary and Michaely (2011), but here we focus only on the largest and most mature firms.

${ }^{33}$ This means that firm's that have a high conditional probability of having low unused debt capacity will smooth their dividends more. Which means that firms that have depleted their borrowing potential have an incentive to preserve access to financial markets. They do this by making sure they provide investors with stable dividends.
} 
Column 5 (our baseline model) then includes all our variables of interest. ${ }^{34} \mathrm{We}$ find that the aforementioned results hold. We explain the nonlinearity of unused debt capacity in two steps. First, we find that the linear and squared terms of unused debt capacity have opposite signs. This implies a bell-shaped relation with dividend smoothing. The economic rational is as follows. At high levels of unused debt capacity, we find a positive relation. This means firms tap into their debt capacity to smooth dividends, consistent with the predictions from Lambrecht and Myers (2012). However, this behavior only occurs when firms have sufficient levels of unused debt capacity. In our setup, this means that there is an "infliction point". That is, a point beyond which firms start to smooth dividends more as their unused debt capacity increases. We calculate this point to be at 43 percent. Therefore, firms in our sample start to smooth their dividends more when they can borrow approximately 43 percent of their asset value before losing their investment grade rating. ${ }^{35}$ At low levels of unused debt capacity (below the infliction point), we find a negative relation with dividend smoothing. Put differently, at low levels of unused debt capacity, firms change their payouts quickly in response to changes in income. This behavior reduces information asymmetry, the benefit of which is that firms preserve (low-cost) access to public debt markets. This finding is consistent with prior literature (e.g., DeAngelo and DeAngelo, 2007 and Denis, 2011; Leary and Michaely, 2011). ${ }^{36}$

Our second step in explaining the nonlinear relation between unused debt capacity and dividend smoothing examines marginal effects. The nonlinear relation implies that at different levels of unused debt capacity, firms exhibit different smoothing behaviors. We calculate the marginal effects at each point on the relevant span of unused debt capacity. Figure 1 shows our calculation including the $95 \%$ confidence intervals. We find that the marginal effects are

\footnotetext{
${ }^{34} \mathrm{We}$ find that leverage is no longer statistically significant. As per good reason, the effect leverage picks up in our first four models is that of capital structure adjustment costs and the firm's level of unused debt capacity. When excluding leverage from the control variables we find that our results are robust.

${ }^{35}$ This level of 43 percent may seem relatively high. However, our sample considers only very large, mature firms with a good history of dividend payments. As such, the likelihood of these firms losing their investment grade rating is relatively low. Also, 43 percent is less than one standard deviation away from the average unused debt capacity firms have in our sample.

${ }^{36}$ We find that the residuals of our baseline model (model 5 in table 3 ) are uncorrelated with the shutdown ( $Z_{t}^{\prime \prime}$ ) variable used equation 11 , and thus do not affect the firms smoothing policies $(\rho \approx 0.02)$. We consider three alternative channels through which government shutdowns could have an impact on dividend smoothing. We look at possible changes in the investment opportunity set, changes in profitability and changes in the value of collateral. We find that the firm's investment opportunity set does not change when faced with a government shutdown. More explicitly, we find that the correlation between shutdowns $(\mathrm{CRs})$ and growth opportunities to be very limited $(\rho \approx 0.07)$. For profitability, we find that the correlation between government shutdowns (CRs) and firm profitability is approximately zero. We conclude that government shutdowns have no effect on dividend smoothing through this channel. With respect to the firm's collateral, which decreases in value as uncertainty increase, we find that we find that the correlation between shutdowns $(\mathrm{CRs})$ and collateral is economically insignificant $(\rho \approx 0.05)$. We conclude that including shutdowns or CRs in our binary response model is valid. The reported correlations also hold when excluding the inverse Mills from the baseline model.
} 
statistically significant at conventional levels across the distribution. ${ }^{37}{ }^{38} \mathrm{We}$ use two examples to demonstrate the intuition and the effect sizes. Consider a firm with relatively low unused debt capacity (0.18). A one standard deviation increase of the firm's unused debt capacity will prompt 9.5 percent less dividend smoothing. ${ }^{39}$ Next, consider a firm with relatively high unused debt capacity (0.53). We find that a one standard deviation increase will prompt approximately 4 percent more dividend smoothing. The significance of the marginal effects and the economic magnitude of our variables of interest, which are comparable to that of our other variables, prompt the following conclusion. Unused debt capacity and capital structure adjustment speeds are valuable in explaining cross-sectional differences in observed Lintner-like dividend smoothing behavior.

\subsection{Shocks to income}

We then test the prediction from Lambrecht and Myers (2012) that the firm's capital structure absorbs shocks to net income in order to enable dividend smoothing. We identify two types of shocks: positive and negative changes in net income. Additionally, we identify severe shocks (fourth quartile changes in net income). These shocks are changes to net income (scaled by total assets) larger than 2 percent. ${ }^{40}$ We consider shocks absorbed in case changes in net income do not lead to changes in dividends.

Table 4 panel A shows the results of our estimations, including shocks to the firm's income. Columns 1 through 3 show the effects of shocks to the firm's dividend smoothing (regardless of the type and severity of the shock). Column 1 shows that when firms are faced with a shock to income, they will smooth their dividends more. The variable shock type has a negative and significant coefficient. This means that in the presence of a shock, firms will smooth their dividends approximately 0.9 percent more. This effect is, however, not economically significant. Column 1 also shows how firms use their debt capacity in case of a shock. At high levels of unused debt capacity, we find an additional positive relation. However, we find that at low levels of unused debt capacity, this relation is negative. We conclude that firms use their debt capacity to offset

\footnotetext{
${ }^{37}$ A possible reason for observing spurious non-linear effects can be outliers in our measure for unused debt capacity (at either side of the distribution). However, this is not the case. To check the robustness of our results we winsorize the unused debt capacity variable at conventional levels. We find that all our results are robust.

${ }^{38}$ For good reasons, the marginal effects are insignificant around the inflection point.

${ }^{39}$ When using sub-sample averages and standard deviations, our results are similar for the effect sizes we obtain.

${ }^{40}$ Alternative definitions of shocks to the firm's income yield similar results.
} 
shocks to income. Column 2 shows only the inclusion of a shock and the firm's capital structure adjustment speed. We find that when not taking into account the firm's unused debt capacity, shocks to the firm's income lead to less dividend smoothing. This finding is in line with the predictions of Lambrecht and Myers (2012). Consistent with the aforementioned, we find that the firm's capital structure adjustment speed has a positive relation with dividend smoothing in the case of a shock. That is, when faced with a shock to income, firms smooth their dividends 3.2 percent more for every percentage increase in their capital structure adjustment speed. This is an added marginal effect, on top of 1.5 percent more dividend smoothing when there is no shock to the firm's income.

Column 3 then combines our variables of interest. We find that the variable shock type is no longer statistically significant. This implies that the firm's capital structure absorbs shocks to net income in such a way that it enables dividend smoothing. This finding is consistent with Hoang and Hoxha (2016) and Daniel et al. (2010). Overall, our conclusion from this analysis is twofold. First, firms offset the effects of shock to their income by absorbing the shocks through their capital structure. Second, the firm's capital structure remains relevant for the firm's dividend smoothing behavior when not faced with a shock to the firm's income. This means that minor changes in net income are also absorbed to enable smooth dividends.

Column 4 then examines how negative shocks to the firm's income are absorbed. Our results are somewhat surprising. We find that firms do not absorb negative shocks to the firms' income. That is, when faced with a negative shock, firms will smooth their dividends approximately 1.3 percent less (i.e., compared to the firms without a negative shock). Moreover, firms that face low capital structure adjustment costs will smooth their dividends even less. This finding, though surprising, is actually quite intuitive. Consider a firm with relatively low capital structure adjustment costs (e.g., the firm can borrow at low costs). When faced with a negative shock to its net income, the firm will have an incentive to inform investors about the positive outlook for the firm. This implies the firm will borrow money to pay an increased dividend. This behavior is possible, because the firm faces only limited adjustment costs. However, while the aforementioned result only takes the type of shock into account (i.e., negative), the group with which we compare the effect contains firms that deal with positive shock or other changes to income. This means that the severity of the shock might also be important. 
As such, for each firm we calculate whether they experienced a fourth quartile shock in every year (i.e., a severe shock). Table 4 panel B shows the result of our estimation. In column 1 we distinguish between severe negative shocks, negative shocks and severe positive shocks. As such, the control group are those firms that experience no shock, positive shocks that are not severe or changes in the firm's income that are not considered to be shocks. Our results are threefold. First, the control group uses its unused debt capacity and capital structure adjustment costs to absorb changes in income (Lambrecht and Myers, 2012). Second, firms that experience a severe negative shock to net income do not differ statistically significantly from the control group in using their capital structure to absorb the effect of the shock, hence the insignificant coefficients on unused debt capacity and capital structure adjustment speeds. However, the severe negative shocks decrease dividend smoothing by approximately 2.3 percent. Third, we find that firms facing a severe positive shock to income will smooth their dividends less (approximately 4 percent). Additionally, when faced with a severe positive shock to net income, firms will smooth their dividends more when they face low costs in adjusting their capital structure. That is, for each percentage of lower capital structure adjustment costs, they will smooth their dividends 8.8 percent more compared to the control group. More intuitively, firms that are able to adjust their capital structure quickly in response to a severe positive shock smooth their dividends more. We conclude that severe positive shocks expose firms to the agency costs of excess cash and hence prompt smoothing behavior (Leary and Michaely, 2011; DeAngelo and DeAngelo, 2007). This finding is consistent with the dynamic agency model from Lambrecht and Myers (2012).

In column 2 we only look at positive changes in the firm's income. The control group then consists of firms that are faced with negative changes in their income. Our findings are again threefold. First, we find that positive changes to income lead to more dividend smoothing at high levels of unused debt capacity. However, at low levels of unused debt capacity, this relation is negative. Second, firms that face positive changes to their income will smooth their dividends less as capital structure adjustment costs decrease. Third, firms that face negative changes will smooth their dividends more at higher levels of unused debt capacity. Again, at low levels this effect is negative. However, for firms facing negative changes, dividend smoothing does not depend on the firm's capital structure adjustment speed. Albeit counter intuitive at first, this finding is consistent with earlier predictions. Consider the following. Given that dividend cuts are costly and external financing costs increase with information asymmetry, firms will not consider adjustment costs in 
the face of negative changes to income. More explicitly, firms have a preference to preserve access to public debt markets (DeAngelo et al., 2007 and Denis, 2011; Leary and Michaely, 2011) and prefer to limit (future) external financing costs (Faulkender et al., 2012).

Overall, the analysis shown in Table 4 panel A and panel B merits three conclusions. First, firms absorb shocks to income through their capital structure to enable dividend smoothing, consistent with predictions from Lambrecht and Myers (2012). Second, irrespective of the type or the severity of the shock, firms will always attempt to smooth their dividends when the level of unused debt capacity is sufficient and when capital structure adjustment costs are low. Third, the absorption of shocks is asymmetric. We conclude that positive and negative shocks are absorbed differently, an attribute not predicted by Lambrecht and Myers (2012). ${ }^{41}$

\subsection{Robustness}

To check the robustness of our results for alternative and omitted variables, we execute additional analysis using our baseline model. Table 5 shows, in columns 1 through 4 , the inclusion of the WW-index as a measure of financial constraints (Whited and $\mathrm{Wu}, 2006$ ). Firms that have more financial constraints will smooth their dividends more. However, when we include the firm's unused debt capacity, this effect is no longer statistically significant, nor is it economically significant. We conclude that financial constraints (as measured by the WW-index) are a very broad measure of the firm's financial flexibility. ${ }^{42}$ However, firms have more specific considerations when determining dividend smoothing.

In column 5, we check the robustness of our results by including the forward inverse Mills ratio of the firms unused debt capacity. That is, the conditional probability that in future periods the firm will face restricted debt capacity. We find a positive relation with dividend smoothing. Firms that expect to face restricted debt capacity in the future will smooth dividends now to

\footnotetext{
${ }^{41}$ Additionally, our findings raise some interesting questions for further research. For example, we document a non-linear effect of the firm's unused debt capacity on dividend smoothing behavior. This bell-shaped relation could imply that there exists a trade-off. At high levels financial flexibility, firms will smooth dividends in such a way that they preserve low-cost access to capital markets. At low levels of financial flexibility, firms will change their dividends more quickly. In the spirit of Lambrecht and Myers (2012), at low levels of financial flexibility, changes in dividends will have more "information content". The trade-off would then be as follows. Firms choose the stability of their dividends in such a manner that they trade between the benefit of information content of payout changes and costs of external financing (low-cost access to public debt markets). In light of Farre-Mensa et al. (2014), who state that the prevalence of smoothing practices is puzzling as there is a lack of evidence to suggest that stock prices or the cost of capital are improved by smooth dividends, understanding the aforementioned trade-off in this paper could be a way forward in the literature.

${ }^{42}$ Prior literature on financial constraints has shown that more constrained firms are most likely to face high agency costs. For example, they may face higher costs of underinvestment. As such, our finding that firms that are more constrained smooth their dividends more is not surprising. However, our measure of unused debt capacity is more fundamental than the broad WW-index. Moreover, our analysis focuses on large and mature firms with a history of credible dividend payments, as such a negative coefficient is not surprising.
} 
maintain low cost access to capital markets. Additionally, in column 6, we interact this variable with a dummy variable indicating high external financing demand. We find that firms with more external financing demand will smooth dividends more. This finding strengthens our earlier conclusions. More importantly, we find that all our results hold.

Additionally, we correct our estimates for target payout ratios, high capital costs (Warr et al., 2012), information asymmetry (analyst forecast deviations), governance (Gompers et al., 2003), taxes and share repurchases. We find that all our results hold for these potentially omitted variables. $^{43}$

\section{Conclusion}

Using Lintner's (1956) model, we examine how financial flexibility relates to dividend smoothing. We conclude that financial flexibility, measured by the firm's unused debt capacity and capital structure adjustment costs, is an important consideration for firms when setting their dividend smoothing policies. Our findings are in line with predictions from Lambrechts and Myers (2012) who state that the firm's capital structure must absorb shocks to the firm's income. More specifically, we show that firms tap into their unused debt capacity to smooth dividends. Additionally, firms that face lower costs in adjusting their capital structure will also smooth dividends more. Our analysis highlights that firms will always exhibit this behavior. However, shocks to income amplify this behavior and are absorbed to enable dividend smoothing. This finding is in line with the results from Hoang and Hoxha (2016) and Daniel et al. (2010). Moreover, we find that shocks are absorbed in a fashion that is asymmetric; that is, positive and negative changes are not absorbed equally. This asymmetry is not predicted by Lambrecht and Myers (2012), nor is it part of the analysis in Hoang and Hoxha (2016). First, we explicitly test the predictions from Lambrecht and Myers (2012). Second, we show that financial flexibility is an important determinant of dividend smoothing. Overall, we conclude that the firm's financial flexibility is at the very least an important factor in understanding differences in dividend smoothing behavior.

\footnotetext{
${ }^{43}$ The results of these robustness tests are available upon request.
} 


\section{References}

Aivazian, V. A., Booth, L., \& Cleary, S. (2006). Dividend smoothing and debt ratings. Journal of Financial and Quantitative Analysis, 41(2), 439-453.

Almeida, H., Campello, M., \& Weisbach, M. S. (2004). The cash flow sensitivity of cash. The Journal of Finance, 59(4), 1777-1804.

Alti, A. (2006). How persistent is the impact of market timing on capital structure?. The Journal of Finance, 61(4), 1681-1710.

Altınkılıç, O., \& Hansen, R. S. (2000). Are there economies of scale in underwriting fees? Evidence of rising external financing costs. The Review of Financial Studies, 13(1), 191-218.

Ashbaugh-Skaife, H., Collins, D. W., \& LaFond, R. (2006). The effects of corporate governance on firms' credit ratings. Journal of Accounting and Economics, 42(1-2), 203-243.

Berk, J. B., \& DeMarzo, P. M. (2007). Corporate Finance. Pearson Education.

Byoun, S. (2008). How and when do firms adjust their capital structures toward targets?. The Journal of Finance, 63(6), 3069-3096.

Daniel, N. D., Denis, D. J., \& Naveen, L. (2010). Sources of Financial Flexibility: Evidence from Cash Flow Shortfalls. Unpublished working paper.

de Jong, A., Verbeek, M., \& Verwijmeren, P. (2012). Does financial flexibility reduce investment distortions?. Journal of Financial Research, 35(2), 243-259.

DeAngelo, H., \& DeAngelo, L. (2007). Payout policy pedagogy: what matters and why. European Financial Management, 13(1), 11-27. 
DeAngelo, H., DeAngelo, L., \& Skinner, D. J. (2004). Are dividends disappearing? Dividend concentration and the consolidation of earnings. Journal of Financial Economics, 72(3), 425-456.

DeAngelo, H., DeAngelo, L., \& Stulz, R. M. (2006). Dividend policy and the earned/contributed capital mix: a test of the life-cycle theory. Journal of Financial Economics, 81(2), 227-254.

Denis, D. J. (2011). Financial flexibility and corporate liquidity. Journal of Corporate Finance, 17(3), 667-674.

Denis, D. J., \& McKeon, S. B. (2012). Debt financing and financial flexibility evidence from proactive leverage increases. The Review of Financial Studies, 25(6), 1897-1929.

Dewenter, K. L., \& Warther, V. A. (1998). Dividends, asymmetric information, and agency conflicts: Evidence from a comparison of the dividend policies of Japanese and US firms. The Journal of Finance, 53(3), 879-904.

Fama, E. F., \& Babiak, H. (1968). Dividend policy: An empirical analysis. Journal of the American Statistical Association, 63(324), 1132-1161.

Fama, E. F., \& French, K. R. (2001). Disappearing dividends: changing firm characteristics or lower propensity to pay? Journal of Financial Economics, 60(1), 3-43.

Fama, E. F., \& French, K. R. (2002). Testing trade-off and pecking order predictions about dividends and debt. The Review of Financial Studies, 15(1), 1-33.

Farre-Mensa, J., Michaely, R., \& Schmalz, M. (2014). Payout policy. Annual Review of Financial Economics, 6(1), 75-134.

Faulkender, M., Flannery, M. J., Hankins, K. W., \& Smith, J. M. (2012). Cash flows and leverage adjustments. Journal of Financial Economics, 103(3), 632-646. 
Fischer, E. O., Heinkel, R., \& Zechner, J. (1989). Dynamic capital structure choice: Theory and tests. The Journal of Finance, 44(1), 19-40.

Flannery, M. J., \& Rangan, K. P. (2006). Partial adjustment toward target capital structures. Journal of Financial Economics, 79(3), 469-506.

Gamba, A., \& Triantis, A. (2008). The value of financial flexibility. The Journal of Finance, 63(5), 2263-2296.

Gompers, P., Ishii, J., \& Metrick, A. (2003). Corporate governance and equity prices. The Quarterly Journal of Economics, 118(1), 107-156.

Graham, J. R., \& Harvey, C. R. (2001). The theory and practice of corporate finance: Evidence from the field. Journal of Financial Economics, 60(2-3), 187-243.

Grullon, G., \& Michaely, R. (2002). Dividends, share repurchases, and the substitution hypothesis. The Journal of Finance, 57(4), 1649-1684.

Guttman, I., Kadan, O., \& Kandel, E. (2010). Dividend stickiness and strategic pooling. The Review of Financial Studies, 23(12), 4455-4495.

Hoang, E. C., \& Hoxha, I. (2016). Corporate payout smoothing: a variance decomposition approach. Journal of Empirical Finance, 35, 1-13.

Hovakimian, A. (2006). Are observed capital structures determined by equity market timing?. Journal of Financial and Quantitative analysis, 41(1), 221-243.

Jensen, M. C. (1986). Agency costs of free cash flow, corporate finance, and takeovers. The American Economic Review, 76(2), 323-329. 
Korajczyk, R. A., \& Levy, A. (2003). Capital structure choice: macroeconomic conditions and financial constraints. Journal of Financial Economics, 68(1), 75-109.

Kosar, K. R. (2004). Shutdown of the federal government: causes, effects, and process. Congressional Research Service, Library of Congress.

Kumar, P. (1988). Shareholder-manager conflict and the information content of dividends. The Review of Financial Studies, 1(2), 111-136.

Kumar, P., \& Lee, B. S. (2001). Discrete dividend policy with permanent earnings. Financial Management, 55-76.

Lambrecht, B. M., \& Myers, S. C. (2012). A Lintner model of payout and managerial rents. The Journal of Finance, 67(5), 1761-1810.

Lambrecht, B. M., \& Myers, S. C. (2017). The dynamics of investment, payout and debt. The Review of Financial Studies, 30(11), 3759-3800.

Leary, M. T., \& Michaely, R. (2011). Determinants of dividend smoothing: Empirical evidence. The Review of Financial Studies, 24(10), 3197-3249.

Leary, M. T., \& Roberts, M. R. (2005). Do firms rebalance their capital structures?. The Journal of Finance, 60(6), 2575-2619.

Lemmon, M. L., \& Zender, J. F. (2010). Debt capacity and tests of capital structure theories. Journal of Financial and Quantitative Analysis, 45(5), 1161-1187.

Lintner, J. (1956). Distribution of incomes of corporations among dividends, retained earnings, and taxes. The American Economic Review, 46(2), 97-113. 
Meyers, R. T. (1997). Late appropriations and government shutdowns: Frequency, causes, consequences, and remedies. Public Budgeting \& Finance, 17(3), 25-38.

Michaely, R., \& Roberts, M. R. (2011). Corporate dividend policies: Lessons from private firms. The Review of Financial Studies, 25(3), 711-746.

Miller, M. H., \& Scholes, M. S. (1978). Dividends and taxes. Journal of Financial Economics, 6(4), 333-364.

Myers, S. C. (1984). The capital structure puzzle. The Journal of Finance, 39(3), 574-592.

Rajan, R. G., \& Zingales, L. (1998). Financial dependence and growth. The American Economic Review, 88(3), 559.

Stefanescu, I., \& Shivdasani, A. (2010). How do pensions affect capital structure decisions?. The Review of Financial Studies, 23, 1287-1323.

Strebulaev, I. A. (2007). Do tests of capital structure theory mean what they say?. The Journal of Finance, 62(4), 1747-1787.

Warr, R. S., Elliott, W. B., Koëter-Kant, J., \& Öztekin, Ö. (2012). Equity mispricing and leverage adjustment costs. Journal of Financial and Quantitative Analysis, 47(3), 589-616.

Whited, T. M., \& Wu, G. (2006). Financial constraints risk. The Review of Financial Studies, 19(2), 531-559. 


\section{Tables and Figures}

\section{Table 1: Variables and definitions}

\begin{tabular}{|c|c|}
\hline Dividend adjustment speed & Equation 2 \\
\hline Unused debt capacity & Equation 7 \\
\hline Capital structure adjustment speed & Equation 9 \\
\hline Number of years in CRSP & Number of years a firm has been included in CRSP \\
\hline Leverage & The sum of short-term and long-term debt divided by total assets \\
\hline Market-to-Book & The market value of equity plus the book value of assets minus the book value of equity, all divided by the book value of assets \\
\hline Firm size (ln) & Total assets (mln, corrected 2013 inflation) \\
\hline Profitability & Net income to total assets \\
\hline Tangibility & Net property plant and equipment to total assets \\
\hline Cash & Cash to total assets \\
\hline Earnings volatility (ln) & Standard deviation of operating income before depreciation \\
\hline Net income shock (dummy) & Equal to one if the absolute change in profitability is larger than $2 \%$ of total assets \\
\hline Negative net income shock (dummy) & Equal to one if the absolute change in profitability is larger than $2 \%$ of total assets and negative \\
\hline Severe net income shock & Fourth quartile income shock \\
\hline Positive income shock & Equal to one if the change in profitability is negative \\
\hline \multicolumn{2}{|l|}{ Robustness variables } \\
\hline WW-index & $\begin{array}{l}\text { As in Whited and } \mathrm{Wu}(2006) ;-0.091 \mathrm{CF}_{\mathrm{it}}-0.062 \mathrm{DIVPOS}_{\mathrm{it}}+0.021 \mathrm{TLTD}_{\mathrm{it}}-0.044 \mathrm{LNTA}_{\mathrm{it}}+0.102 \mathrm{ISG}_{\mathrm{it}}-0.035 \mathrm{SG}_{\mathrm{it}} \text {, where CF is cash flows, DIVPOS is } \\
\text { indicator (1) if firms pays dividend, TLTD is long term debt to total assets, LNTA is natural log of total assets, ISG is firm's 3-digit industry sales growth and } \\
\mathrm{SG} \text { is firm's sales growth }\end{array}$ \\
\hline External financing demand & $\begin{array}{l}\text { From Rajan and Zingales (1998); capital expenditures minus cash flow from operations, divided by capital expenditures (taking into account different cash } \\
\text { flow statement formats) }\end{array}$ \\
\hline Target payout ratio & Firm specific median target payout ratio \\
\hline High capital costs (dummy) & Based on Warr et al. (2012); Equal to 1 if a firm at some point in time, was above its target leverage and had a market-to-book value below 1; otherwise 0 \\
\hline Forecast deviation & Deviation of earnings from median analyst forecast \\
\hline Governance index & Obtained from Gomperts et al. (2003); available at http://faculty.som.yale.edu/andrewmetrick/data.html \\
\hline Taxes & Current taxes to total assets \\
\hline Marginal Tax rate & Current taxes to net income \\
\hline Change in common shares outstanding & Change in shares outstanding \\
\hline Repurchase (dummy) & Equal to one if the reduction in common shares outstanding is more than $10 \%$ \\
\hline Repurchasing activity & Total number of repurchases executed during the Compustat/CRSP listing for each unique firm \\
\hline
\end{tabular}


Table 2: Descriptive statistics

\begin{tabular}{|c|c|c|c|c|c|c|}
\hline Variables & Mean & p50 & p25 & p75 & SD & $\mathbf{N}$ \\
\hline Dividend adjustment speed & 0.315 & 0.283 & 0.084 & 0.477 & 0.265 & 5,159 \\
\hline Unused debt capacity & 0.319 & 0.289 & 0.085 & 0.494 & 0.265 & 5,159 \\
\hline Capital structure adjustment speed & 0.447 & 0.411 & 0.220 & 0.655 & 0.291 & 5,159 \\
\hline Number of years in CRSP & 34.71 & 38.00 & 24.00 & 45.00 & 13.89 & 5,159 \\
\hline Leverage & 0.260 & 0.253 & 0.178 & 0.334 & 0.121 & 5,159 \\
\hline Market-to-Book & 1.773 & 1.485 & 1.168 & 2.008 & 1.003 & 5,159 \\
\hline Firm size (millions, adjusted for inflation base year 2013) & 9075.25 & 2940.97 & 1224.10 & 8484.81 & 19154.24 & 5,159 \\
\hline Profitability & 0.061 & 0.059 & 0.031 & 0.089 & 0.059 & 5,159 \\
\hline Tangibility & 0.373 & 0.326 & 0.220 & 0.505 & 0.200 & 5,159 \\
\hline Cash & 0.052 & 0.031 & 0.013 & 0.069 & 0.058 & 5,159 \\
\hline Earnings volatility (ln) & 6.144 & 6.080 & 5.190 & 7.121 & 1.448 & 5,159 \\
\hline Net income shock (dummy) & 0.442 & 0.000 & 0.000 & 1.000 & 0.497 & 5,155 \\
\hline Negative net income shock (dummy) & 0.224 & 0.000 & 0.000 & 0.000 & 0.417 & 5,155 \\
\hline Severe net income shock & 0.248 & 0.000 & 0.000 & 0.000 & 0.432 & 5,155 \\
\hline Positive income shock & 0.523 & 1.000 & 0.000 & 1.000 & 0.500 & 5,155 \\
\hline \multicolumn{7}{|c|}{ Robustness variables } \\
\hline WW-index & 0.646 & 0.660 & 0.149 & 1.119 & 1.051 & 5,155 \\
\hline High external financing demand (dummy) & 0.441 & 0.000 & 0.000 & 1.000 & 0.497 & 5,159 \\
\hline Target payout ratio & 0.367 & 0.362 & 0.248 & 0.469 & 0.170 & 5,159 \\
\hline High capital costs (dummy) & 0.193 & 0.000 & 0.000 & 0.000 & 0.395 & 5,159 \\
\hline Forecast deviation & 0.049 & 0.006 & -0.049 & 0.118 & 0.713 & 4,141 \\
\hline Governance index & 9.336 & 9.333 & 7.500 & 11.250 & 2.543 & 3,365 \\
\hline Taxes & 0.034 & 0.030 & 0.016 & 0.048 & 0.025 & 4,046 \\
\hline Marginal Tax rate & 0.573 & 0.485 & 0.311 & 0.632 & 3.540 & 4,046 \\
\hline Change in common shares outstanding & 0.109 & 0.002 & -0.011 & 0.015 & 0.391 & 4,968 \\
\hline Repurchase (dummy) & 0.018 & 0.000 & 0.000 & 0.000 & 0.133 & 4,968 \\
\hline Repurchasing activity & 0.56 & 0.00 & 0.00 & 1.00 & 0.82 & 4,968 \\
\hline
\end{tabular}




\title{
Table 3: Understanding dividend smoothing, building a baseline model
}

\begin{abstract}
Variables are defined as in Table 1; the dependent variable is SOA (speed of dividend adjustment). The variable leverage has been made orthogonal to the other control variables. The inverse Mills ratio for the endogenous choice of high unused debt capacity has been made orthogonal to the inverse Mills of leverage and other control variables. In addition, the inverse Mills of leverage has been made orthogonal to the control variables. The estimation is a FGLS (feasible generalized least squares), with an identity link function. We correct the standard errors for a heteroskedastic error structure with no cross-sectional correlation. All estimations include a panel-specific AR1 autocorrelation structure, where the autocorrelation parameter is specified by the Durbin-Watson statistic.
\end{abstract}

\begin{tabular}{|c|c|c|c|c|c|}
\hline Variables & (1) & (2) & (3) & (4) & $(5)$ \\
\hline Unused debt capacity & & & $\begin{array}{c}0.196 * * * \\
(0.000)\end{array}$ & & $\begin{array}{c}0.194 * * * \\
(0.000)\end{array}$ \\
\hline Unused debt capacity (squared) & & & $\begin{array}{c}-0.228 * * * \\
(0.000)\end{array}$ & & $\begin{array}{c}-0.224 * * * \\
(0.000)\end{array}$ \\
\hline Capital structure adjustment speed & & & & $\begin{array}{c}-0.028 * * * \\
(0.000)\end{array}$ & $\begin{array}{c}-0.025 * * * \\
(0.000)\end{array}$ \\
\hline Leverage & $\begin{array}{c}-0.114 * * * \\
(0.000)\end{array}$ & $\begin{array}{c}-0.113 * * * \\
(0.000)\end{array}$ & $\begin{array}{c}-0.047 * \\
(0.094)\end{array}$ & $\begin{array}{c}-0.108 * * * \\
(0.000)\end{array}$ & $\begin{array}{l}-0.046 \\
(0.102)\end{array}$ \\
\hline Market-to-book & $\begin{array}{c}0.002 \\
(0.431)\end{array}$ & $\begin{array}{c}0.002 \\
(0.467)\end{array}$ & $\begin{array}{c}-0.001 \\
(0.805)\end{array}$ & $\begin{array}{c}0.000 \\
(0.961)\end{array}$ & $\begin{array}{c}-0.001 \\
(0.667)\end{array}$ \\
\hline Size $(\ln )$ & $\begin{array}{c}0.030 * * * \\
(0.000)\end{array}$ & $\begin{array}{c}0.030 * * * \\
(0.000)\end{array}$ & $\begin{array}{c}0.039 * * * \\
(0.000)\end{array}$ & $\begin{array}{c}0.043 * * * \\
(0.000)\end{array}$ & $\begin{array}{c}0.036 * * * \\
(0.000)\end{array}$ \\
\hline Profitability & $\begin{array}{c}-0.002 \\
(0.952)\end{array}$ & $\begin{array}{l}-0.003 \\
(0.931)\end{array}$ & $\begin{array}{c}0.011 \\
(0.749)\end{array}$ & $\begin{array}{c}0.049 \\
(0.116)\end{array}$ & $\begin{array}{c}0.003 \\
(0.940)\end{array}$ \\
\hline Tangibility & $\begin{array}{c}0.121 * * * \\
(0.000)\end{array}$ & $\begin{array}{c}0.119 * * * \\
(0.000)\end{array}$ & $\begin{array}{c}0.120 * * * \\
(0.000)\end{array}$ & $\begin{array}{c}0.117 * * * \\
(0.000)\end{array}$ & $\begin{array}{c}0.113 \text { *** } \\
(0.000)\end{array}$ \\
\hline Cash & $\begin{array}{c}0.073 * * \\
(0.033)\end{array}$ & $\begin{array}{c}0.073 * * \\
(0.033)\end{array}$ & $\begin{array}{c}0.131 * * * \\
(0.000)\end{array}$ & $\begin{array}{c}0.144 * * * \\
(0.000)\end{array}$ & $\begin{array}{c}0.133^{* * * *} \\
(0.000)\end{array}$ \\
\hline Earnings volatility $(\ln )$ & $\begin{array}{c}-0.008 * \\
(0.086)\end{array}$ & $\begin{array}{c}-0.008 * \\
(0.084)\end{array}$ & $\begin{array}{c}-0.017 * * * \\
(0.002)\end{array}$ & $\begin{array}{c}-0.019 * * * \\
(0.000)\end{array}$ & $\begin{array}{c}-0.015^{* * *} * \\
(0.005)\end{array}$ \\
\hline Inverse Mills ratio (Unused debt capacity) & & & $\begin{array}{c}-0.321 * * * \\
(0.000)\end{array}$ & $\begin{array}{c}-0.411 * * * \\
(0.000)\end{array}$ & $\begin{array}{c}-0.299 * * * \\
(0.001)\end{array}$ \\
\hline Inverse Mills ratio (Leverage) & & $\begin{array}{c}0.001 \\
(0.975)\end{array}$ & $\begin{array}{c}0.060 * \\
(0.061)\end{array}$ & $\begin{array}{c}0.039 \\
(0.231)\end{array}$ & $\begin{array}{c}0.050 \\
(0.121)\end{array}$ \\
\hline Year FE & YES & YES & YES & YES & YES \\
\hline Industry FE & YES & YES & YES & YES & YES \\
\hline Age deciles & YES & YES & YES & YES & YES \\
\hline Observations & 5,159 & 5,159 & 5,159 & 5,159 & 5,159 \\
\hline Number of firms & 517 & 517 & 517 & 517 & 517 \\
\hline Chi-square & 4,485 & 4,539 & 4,372 & 4,431 & 4,250 \\
\hline
\end{tabular}


Figure 1: Marginal effects of the nonlinearity of unused debt capacity (Table 3 - Model 5 - baseline model)

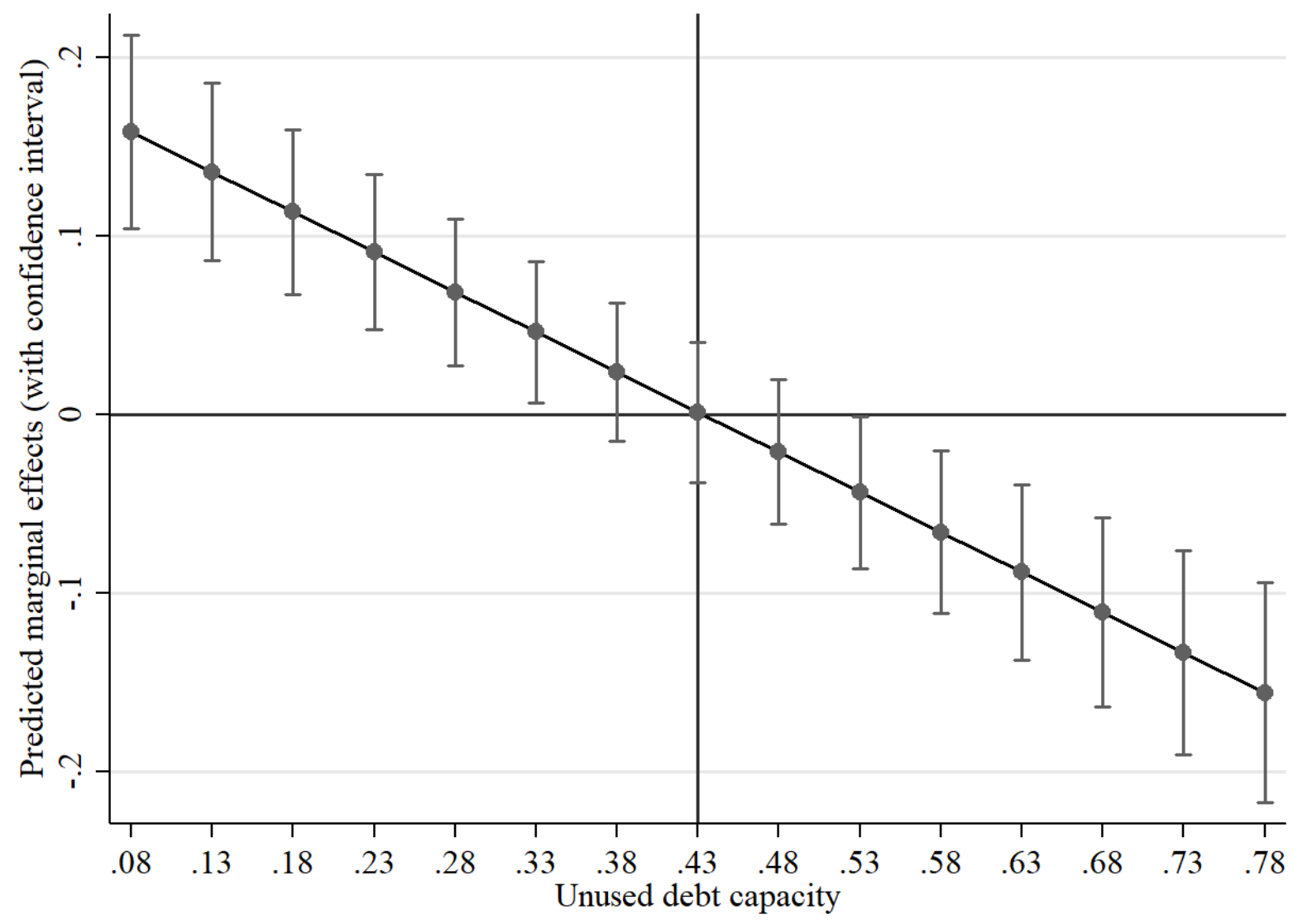




\section{Table 4 - Panel A: Shocks to net income and dividend smoothing}

Variables are defined as in Table 1; the dependent variable is SOA (speed of dividend adjustment). Estimation follows the outline in Table 3. A shock to net income is defined to occur when the absolute change in profitability is larger than $2 \%$ of total assets. A negative shock to net income is defined to occur when the absolute change in profitability is larger than $2 \%$ of total assets and the change is negative.

\begin{tabular}{|c|c|c|c|c|}
\hline & $(1)$ & $(2)$ & (3) & (4) \\
\hline Shock type & \multicolumn{3}{|c|}{ Shocks to net income } & Negative shocks \\
\hline Unused debt capacity x Shock type & $0.103 * * *$ & & $0.097 * * *$ & -0.036 \\
\hline & $(0.000)$ & & $(0.000)$ & $(0.238)$ \\
\hline \multirow{2}{*}{ Unused debt capacity (squared) x Shock type } & $-0.089 * * *$ & & $-0.088 * * *$ & 0.011 \\
\hline & $(0.005)$ & & $(0.006)$ & $(0.756)$ \\
\hline \multirow[t]{2}{*}{ Capital structure adjustment speed x Shock type } & & $-0.032 * * *$ & $-0.022 * *$ & $0.033 * * *$ \\
\hline & & $(0.000)$ & $(0.013)$ & $(0.002)$ \\
\hline \multirow[t]{2}{*}{ Shock type } & $-0.009 * *$ & $0.020 * * *$ & 0.002 & $0.013 *$ \\
\hline & $(0.033)$ & $(0.000)$ & $(0.702)$ & $(0.076)$ \\
\hline \multirow{2}{*}{ Unused debt capacity } & $0.160 * * *$ & & $0.141 * * *$ & $0.182 * * *$ \\
\hline & $(0.000)$ & & $(0.000)$ & $(0.000)$ \\
\hline \multirow[t]{2}{*}{ Unused debt capacity (squared) } & $-0.192 * * *$ & & $-0.175 * * *$ & $-0.228 * * *$ \\
\hline & $(0.000)$ & & $(0.000)$ & $(0.000)$ \\
\hline \multirow[t]{2}{*}{ Capital structure adjustment speed } & & $-0.015 * *$ & $-0.018 * *$ & $-0.030 * * *$ \\
\hline & & $(0.047)$ & $(0.019)$ & $(0.000)$ \\
\hline Controls & YES & YES & YES & YES \\
\hline Inverse Mills ratios & YES & YES & YES & YES \\
\hline Year FE & YES & YES & YES & YES \\
\hline Industry FE & YES & YES & YES & YES \\
\hline Age deciles & YES & YES & YES & YES \\
\hline Observations & 5,155 & 5,155 & 5,155 & 5,155 \\
\hline Number of firms & 517 & 517 & 517 & 517 \\
\hline Chi-square & 4,220 & 4,170 & 4,105 & 4,588 \\
\hline
\end{tabular}




\section{Table 4 - Panel B: Shocks to net income and dividend smoothing}

Variables are defined as in Table 1; the dependent variable is SOA (speed of dividend adjustment). Estimation follows the outline in Table 3. A severe shock to net income is defined as occurred when the change in profitability falls in the fourth quartile of changes to net income. Positive changes to net income are defined as such when the change in profitability is positive.

(1)

(2)

\begin{tabular}{|c|c|c|c|c|}
\hline & \multicolumn{3}{|c|}{$(1)$} & (2) \\
\hline Shock type & Severe negative shocks & Negative shocks & Severe positive shocks & Positive changes \\
\hline \multirow{4}{*}{ Unused debt capacity (squared) x Shock type } & 0.020 & 0.017 & 0.008 & $0.076^{* * *}$ \\
\hline & $(0.675)$ & $(0.695)$ & $(0.862)$ & $(0.001)$ \\
\hline & -0.079 & -0.023 & 0.030 & $-0.049 *$ \\
\hline & $(0.234)$ & $(0.616)$ & $(0.590)$ & $(0.073)$ \\
\hline \multirow[t]{2}{*}{ Capital structure adjustment speed x Shock type } & -0.003 & 0.025 & $-0.088 * * *$ & $-0.026 * * *$ \\
\hline & $(0.845)$ & $(0.108)$ & $(0.000)$ & $(0.001)$ \\
\hline \multirow[t]{2}{*}{ Shock type } & $0.023 * *$ & 0.009 & $0.042 * * *$ & -0.009 \\
\hline & $(0.020)$ & $(0.375)$ & $(0.000)$ & $(0.126)$ \\
\hline \multirow[t]{2}{*}{ Unused debt capacity } & & $0.159 * * *$ & & $0.169 * * *$ \\
\hline & & $(0.000)$ & & $(0.000)$ \\
\hline \multirow[t]{2}{*}{ Unused debt capacity (squared) } & & $-0.204 * * *$ & & $-0.220 * * *$ \\
\hline & & $(0.000)$ & & $(0.000)$ \\
\hline \multirow[t]{2}{*}{ Capital structure adjustment speed } & & $-0.012 * *$ & & -0.010 \\
\hline & & $(0.042)$ & & $(0.216)$ \\
\hline Controls & & YES & & YES \\
\hline Inverse Mills ratios & & YES & & YES \\
\hline Year FE & & YES & & YES \\
\hline Industry FE & & YES & & YES \\
\hline Age deciles & & YES & & YES \\
\hline Observations & & 5,155 & & 5,155 \\
\hline Number of firms & & 517 & & 517 \\
\hline Chi-square & & 4,165 & & 4,444 \\
\hline
\end{tabular}




\section{Table 5: Robustness}

Variables are defined as in Table 1; the dependent variable is SOA (speed of dividend adjustment). Estimation follows the outline in Table 3. In columns 1,2 and 3 leverage is excluded as a control variable. The variable FCPLDC, is the one period forward inverse Mills ratio of the variable unused debt capacity. This variable captures the firm's conditional probability to have low unused debt capacity in future periods.

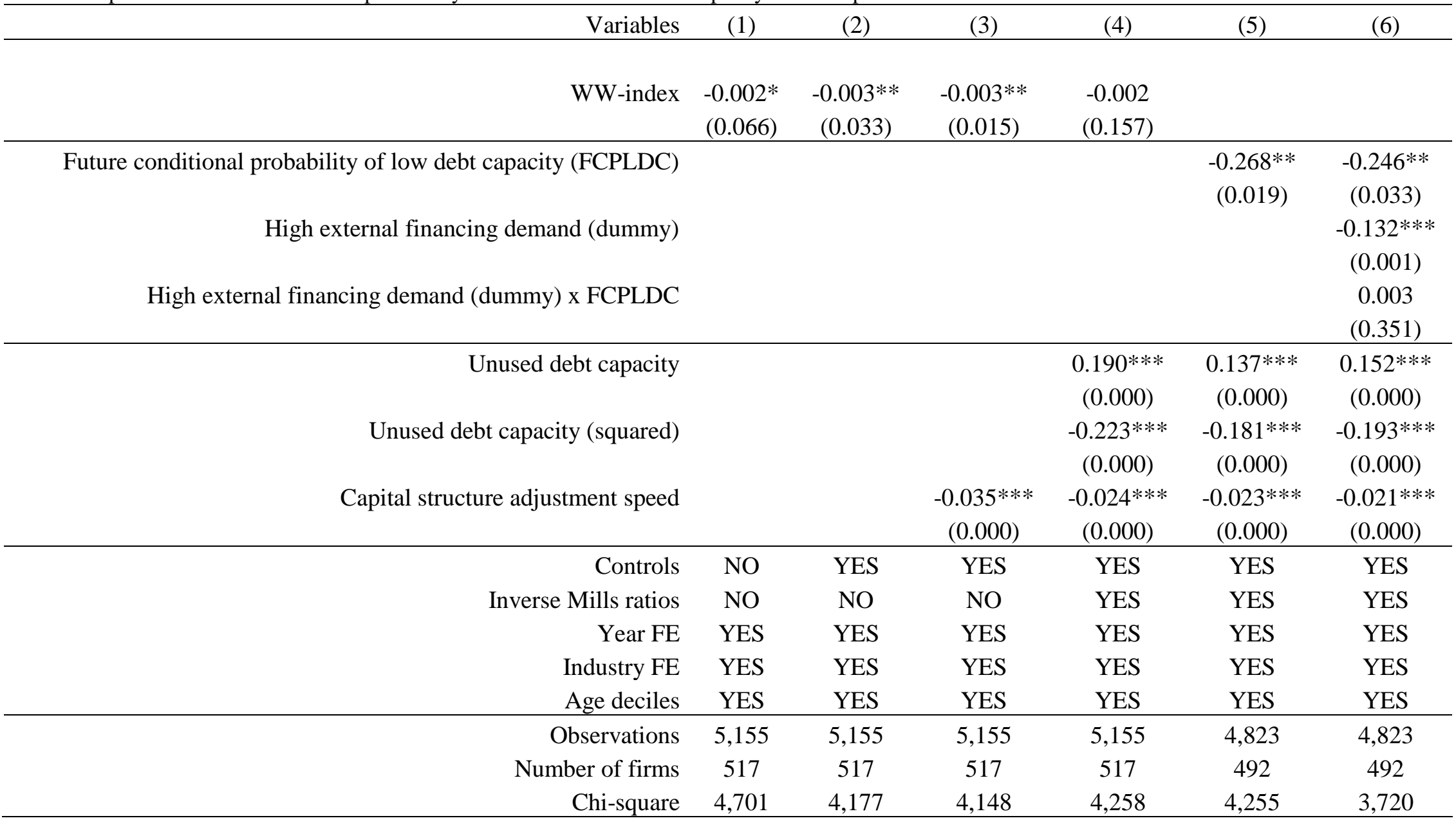

